\title{
Parasitic Arthropods of Some Wild Rodents from Juréia-Itatins Ecological Station, State of São Paulo, Brazil
}

\author{
David Eduardo Paolinetti Bossi, Arício Xavier Linhares $/{ }^{+}$, Helena de Godoy Bergallo*
}

Departamento de Parasitologia, Instituto de Biologia, Universidade Estadual de Campinas, Caixa Postal 6109, 13083-970

Campinas, SP, Brasil *Departamento de Ecologia, Universidade Estadual do Rio de Janeiro, Rio de Janeiro, RJ, Brasil

A study of the associations between three species of rodents in the Atlantic forest and their parasitic arthropods was undertaken at the Juréia-Itatins Ecological Station, located in the State of São Paulo, Southeastern Brazil, from March 1989 to February 1990. Individuals of three species, Oryzomys russatus, Proechimys iheringi and Nectomys squamipes were captured and examined for ectoparasites. Eleven species of parasitic arthropods were found, including four species of insects and seven of Acari. Parasitism intensity, phenology, and rainfall were positively correlated with the abundance of the ectoparasites and their hosts. The most abundant host was O. russatus (Muridae: Sigmodontinae), and the most common parasite on it was the laelapid mite Gigantolaelaps oudemansi. The cuterebrid Metacuterebra apicalis caused myiasis in $\mathrm{O}$. russatus. A mutualistic association between the staphylinid beetle Amblyopinus sp. and its host P. iheringi (Echimyidae) was observed. The few N. squamipes captured had small numbers of ectoparasites.

Key words: rodent ectoparasites - Acari - Diptera - Siphonaptera - Coleoptera - Atlantic rain forest - Brazil

Ectoparasitic arthropods that infest mammals are either insects or acarines (Kettle 1985). Some ectoparasites such as chewing and sucking lice are permanent, whereas most adult fleas and ticks are temporary (Kim 1985). Some ectoparasites are biological vectors of pathogenic organisms (viruses, bacteria, protozoans, and helminths) among their hosts (Kettle 1985).

Some studies that have examined ectoparasites of small mammals in the Brazilian Atlantic forest (Fonseca 1939a, Guimarães 1945, Linardi 1977, Linardi et. al 1984, 1987, 1991, Guitton et al. 1986, Barros \& Baggio 1992, Bossi \& Bergallo 1992, Barros et al. 1993, Carvalho et al. 2001) have included species inventories, taxonomic descriptions, and records of host-parasite associations. Others (Botelho et al. 1981, Barros-Battesti et al. 1998) have evaluated the ectoparasites-host associations. The objectives of the present study were to (1) describe the relationship between three Atlantic forest rodent species and their ectoparasites; (2) assess the degree of host ectoparasite specificity; and (3) examine the influence of rainfall on ectoparasite abundance.

\section{MATERIALS AND METHODS}

The present study was undertaken at the Juréia-Itatins Ecological Station $\left(24^{\circ} 32^{\prime} \mathrm{S} ; 4^{\circ} 15^{\prime} \mathrm{W}\right)$, located in the municipalities of Peruíbe, Iguape, Miracatu and Itariri, State of São Paulo, Southeastern Brazil. The climate is tropical humid, with a mild, dry season from May to September.

\footnotetext{
Work supported by Fapesp, grant \# 88/3649-4, Faep, grant \# 519/88 and CNPq grant \# 301372/95-0.

${ }^{+}$Corresponding author. Fax: +55-19-3788.6282. E-mail: aricio@unicamp.br

Received 20 March 2002

Accepted 9 July 2002
}

Annual rainfall is high (3,000 to 4,000 mm/yr) (Paixão 1984). During the present study, the wettest month was January 1990 (546.3 mm), and the driest was August 1989 (49 mm). For data analysis, the dry and cool period was considered to range from April to September and the wet and warm period from October to March. The mean temperature varies from $18.3^{\circ} \mathrm{C}$ to $25.6^{\circ} \mathrm{C}$, with July being the coolest month and February the warmest (Nascimento \& Pereira 1988).

Field samples were obtained monthly from February 1989 to March 1990. Small mammal trapping was conducted in an irregular grid covering 5 ha, with 14 transects varying from 200 to $240 \mathrm{~m}$, spaced 20-m apart. Wire-cage traps (120) baited with banana or manioc with peanut butter were set on the forest floor for three consecutive nights (Bergallo 1994). Each trap site was recorded and trapped animals were taken to a nearby station laboratory. Handling of small mammals was similar to the procedure used by Gettinger (1992). The animals were placed in plastic bags with a cotton ball soaked with ethyl ether until they became unconscious, after which they were marked using an ear-code (Monteiro-Filho 1987), weighed, and sexed. Larger ectoparasites were removed from the fur, ears and tail with fine combs, toothbrushes or tweezers and stored in $70 \%$ alcohol. The hosts were subsequently released at the same trap site. Ectoparasites that fell from the animals during anesthesia in the plastic bag were also stored in $70 \%$ alcohol.

Analysis of variance was used to test the effect of host species, parasite species and period of the year (dry or wet) on parasite prevalence. Comparisons of parasite relative densities versus host sex were done using Student's $t$-test. In addition to these analyses, prevalence and mean intensity were determined for the most common species. Prevalence is defined as the number of hosts infested with one or more individuals of a particular parasite species or taxonomic group divided by the number of hosts examined for that parasite. Mean intensity is the 
total number of parasites of a particular species found in a sample divided by the number of hosts infested with that parasite (Bush et al. 1997). Overall host and parasite abundances by period of the year (dry or wet) were also analyzed using ANOVA. The analyses were done using the SAS statistical program (SAS Institute 1987).

\section{RESULTS}

A total of 5,350 arthropods specimens infesting 11 species was taken from 80 small rodents, 23 being the spiny rat Proechimys iheringi Thomas, 51 the rice rat Oryzomys russatus (Wagner) and 6 the water rat Nectomys squamipes (Brants). In addition to the rodents, three species of marsupials: Didelphis aurita Wied-Neuwied, Metachirus nudicaudatus (Desmarest), and Philander frenata (Linnaeus) were captured, and the results will be presented elsewere.

Ectoparasites collected were Acari Ixodidae: Amblyomma cajennense (Fabricius), Haemaphysalis leporispalustris (Packard) and Ixodes sp.; Acari Lelapidae: Gigantolaelaps oudemansi Fonseca, Androlaelaps (Haemolaelaps) sp., Gigantolaelaps gilmorei Fonseca; Siphonaptera Rhopalopsyllidae: Polygenis (Polygenis) roberti roberti (Rothschild); Siphonaptera Ctenophthalmidae: Adoratopsylla (Tritopsylla) intermedia intermedia (Wagner); Diptera Cuterebridae: Metacuterebra apicalis (Guérin-Meneville); Coleoptera Staphylinidae: Amblyopinus sp. Siphonaptera nomencla- ture is according to the one proposed by Linardi and Guimarães (2000).

Seven arthropod species, totaling 5,148 individuals, were collected from 139 captures of $O$. russatus. This represented $96.2 \%$ of the ectoparasites collected from all hosts. G. oudemansi was the most frequent species $(3,162$ individuals), and was collected almost exclusively on $O$. russatus. A. (Haemolaelaps) sp. $(\mathrm{n}=550)$ was collected exclusively on $O$. russatus. G. gilmorei $(\mathrm{n}=717), P . r$. roberti $(\mathrm{n}=155), M$. apicalis, a subcutaneous parasite ( $\mathrm{n}$ $=25)$, and Ixodes sp. $(\mathrm{n}=12)$, were also collected almost exclusively on $O$. russatus, but with a frequency much lower than that recorded for G. oudemansi (Table I). Other ectoparasites collected on $O$. russatus included 12 nymphs and 505 larvae of $A$. cajennense.

A total of 202 individuals, belonging to 11 species of arthropods was captured from 75 captures of $P$. iheringi, representing $3.8 \%$ of all arthropods collected on the hosts. The beetle Amblyopinus sp. $(\mathrm{n}=80)$, a mutualistic insect, was collected almost exclusively on this rodent. Twelve Androlaelaps sp., and $3 \mathrm{H}$. leporispalustris were collected exclusively on $P$. iheringi. Other ectoparasites collected on this host included $A$. cajennense (larvae: $\mathrm{n}=67$ ); nymphs: $(\mathrm{n}=15)$, G. oudemansi $(\mathrm{n}=12)$, G. gilmorei $(\mathrm{n}=$ 4), Ixodes sp. $(\mathrm{n}=3)$, P. r. roberti $(\mathrm{n}=5)$ and $A$. i. intermedia $(\mathrm{n}=2)$ (Table I).

Only 8 arthropods of 4 species ( $0.2 \%$ of all specimens) were collected on $N$. squamipes, including G. oudemansi

\section{TABLE I}

Relative density of arthropods recovered from 139 Oryzomys russatus, 75 Proechimys iheringi and 11 Nectomys squamipes at the Juréia-Itatins Ecological Station, State of São Paulo, Brazil, March 1989-February 1990

Oryzomys russatus

\begin{tabular}{|c|c|c|c|c|c|c|c|}
\hline Ectoparasites & Dry months & $(\mathrm{N})$ & Wet months & $(\mathrm{N})$ & DF & $t$ & $P$ \\
\hline A. cajennense (nymphs) & 0.89 & (2) & 0.81 & (7) & 7 & 0.51 & 0.6263 \\
\hline A. cajennense (larvae) & 1.13 & (3) & 0.69 & (3) & 2 & 1.66 & 0.2384 \\
\hline G. gilmorei & 1.63 & $(41)$ & 1.73 & (67) & 673 & 0.67 & 0.5039 \\
\hline G. oudemansi & 2.43 & (73) & 2.45 & $(131)$ & 205 & 0.14 & 0.8888 \\
\hline A. (Haemolaelaps) sp. & 1.65 & (32) & 1.67 & (49) & 79 & 0.14 & 0.8903 \\
\hline Ixodes sp. & 0.75 & $(7)$ & 0.69 & (4) & 6 & 1.0 & 0.3559 \\
\hline M. apicalis & 0.69 & (6) & 0.91 & (12) & 11 & 2.64 & 0.0229 \\
\hline P. r. roberti & 1.07 & $(26)$ & 1.21 & (34) & 571 & 1.26 & 0.2128 \\
\hline \multicolumn{8}{|l|}{ Proechimys iheringi } \\
\hline Arthropods & Dry months & $(\mathrm{N})$ & Wet months & $(\mathrm{N})$ & $\mathrm{DF}$ & $t$ & $P$ \\
\hline A. cajennense (nymphs) & 0.69 & (2) & 0.81 & (10) & 9 & 1.96 & 0.0811 \\
\hline A. cajennense (larvae) & 1.16 & (5) & 1.40 & (12) & 15 & 0.63 & 0.5388 \\
\hline Amblyopinus sp. & 1.17 & (21) & 0.94 & (13) & 32 & 1.36 & 0.1824 \\
\hline G. oudemansi & 1.66 & (2) & 0.92 & (3) & 3 & 2.04 & 0.1343 \\
\hline H. leporispalustris & 0.69 & (2) & - & (1) & - & - & - \\
\hline P. $r$ roberti & 0.69 & (3) & 0.69 & (1) & - & - & - \\
\hline
\end{tabular}

Nectomys squamipes

\begin{tabular}{lccccc}
\hline Arthropods & Dry months (N) & Wet months (N) & DF & $t$ & $P$ \\
\hline A. cajennense (larvae) & $(0)$ & $(2)$ & - & - & - \\
Amblyopinus sp. & $(0)$ & $(1)$ & - & - & - \\
G. oudemansi & $(0)$ & $(4)$ & - & - & - \\
M. apicalis & $(0)$ & $(1)$ & - & - & - \\
\hline
\end{tabular}

A: Amblyoma; G: Gigantolaelaps; A: Androlaelaps; M: Metacutereba; P.r.: Polygenis roberti; N: number of observations; DF: degrees of freedom; $t$ : t-test values; $P$ : probabilities 
$(\mathrm{n}=4)$, A. cajennense larvae $(\mathrm{n}=2)$, Amblyopinus $\mathrm{sp} .(\mathrm{n}=$ 1) and $M$. apicalis $(\mathrm{n}=1)$.

There was no significant relationship between parasite intensity and host sex for any host species. The mean parasite intensities were, respectively, 1.90 and 1.77 , on male and female $O$. russatus $\left(t_{498}=1.27 ; P=0.20\right)$, and 0.97 and 1.10 on male and female $P$. iheringi $\left(t_{572}=1.17\right.$; $P=0.24)$.

The relationship between parasite intensity and period of the year (dry or wet) was significant only for $O$. russatus, with higher values in the wet (1.95) than in the dry (1.72) period $\left(t_{498}=2.58 ; P<0.01\right)$. Parasite intensity on $P$. iheringi during the dry (1.11) and wet (0.96) months did not differ significantly $\left(t_{88}=1.39 ; P=0.16\right)$. $N$. squamipes was captured with ectoparasites only during wet months.

The relationship between the mean numbers of arthropods and the period of the year was significantly different for $M$. apicalis found on $O$. russatus (Table I).

The mean intensity of parasitic arthropods during the wet and dry months was significantly different only for M. apicalis (Table II). This parasite showed a higher intensity of parasitism during the wet period.

Comparisons of the mean intensities among arthropod species were significant for the hosts $O$. russatus $(F$ $=57.39 ; P=0.0001)$ and $P$. iheringi $(F=2.28 ; P=0.0181)$ (Table III). N. squamipes had too few parasites for meaningful statistical analysis. No lice were collected.

\section{DISCUSSION}

The type of traps used in this work did not prevent the ectoparasites from abandoning their hosts. This could have occurred with specimens of Amblyopinus sp., which some species normally remain on the host only at night (Ashe \& Timm 1987). Using combs, toothbrushes or tweezers to sample the hosts could account for the absence of lice in samples, since these ectoparasites usually remain firmly attached to the host. In addition, it was not possible to determine the exact area of the host body where most of the ectoparasites were collected. Bots of $M$. apicalis were located on the lateral thoracic region and

\section{TABLE III}

Total number of arthropods found on Oryzomys russatus and Proechimys iheringi at the Juréia-Itatins Ecological Station, State of São Paulo, Brazil, March 1989-February 1990. The Table shows the number of observations (N) and the mean density per host and standard deviation (SD) of parasite intensities

Oryzomys russatus

\begin{tabular}{lrccc}
\hline Arthropods & N & $\begin{array}{c}\text { Mean } \\
\text { density }\end{array}$ & SD & $\begin{array}{c}\text { Duncan } \\
\text { test } b\end{array}$ \\
\hline G. oudemansi & 207 & 2.44 & 1.00 & $\mathrm{~A}$ \\
G. gilmorei & 108 & 1.70 & 0.74 & $\mathrm{~B}$ \\
A. Haemolaelaps) sp. & 81 & 1.67 & 0.87 & $\mathrm{~B}$ \\
P. roberti & 60 & 1.15 & 0.45 & $\mathrm{~B} / \mathrm{C}$ \\
A. cajennense (larvae) & 6 & 0.91 & 0.38 & $\mathrm{C}$ \\
M. apicalis & 7 & 0.90 & 0.28 & $\mathrm{C}$ \\
A. cajennense (nymphs) & 9 & 0.82 & 0.20 & $\mathrm{C}$ \\
Ixodes sp. & 11 & 0.73 & 0.12 & $\mathrm{C}$ \\
\hline
\end{tabular}

Proechimys iheringi

\begin{tabular}{lrccc}
\hline Arthropods & N & $\begin{array}{c}\text { Mean } \\
\text { density }\end{array}$ & SD & $\begin{array}{c}\text { Duncan } \\
\text { test } b\end{array}$ \\
\hline A. cajennense (larvae) & 17 & 1.33 & 0.71 & $\mathrm{~A}$ \\
G. oudemansi & 5 & 1.22 & 0.53 & $\mathrm{~A}$ \\
Amblyopinus sp. & 34 & 1.08 & 0.46 & $\mathrm{~A}$ \\
Androlaelaps sp. & 8 & 0.89 & 0.21 & $\mathrm{~A}$ \\
A. cajennense (nymphs) & 12 & 0.79 & 0.18 & $\mathrm{~A}$ \\
G. gilmorei & 2 & 0.69 & 0 & $\mathrm{~A}$ \\
H. leporispalustris & 3 & 0.69 & 0 & $\mathrm{~A}$ \\
A. intermedia & 2 & 0.69 & 0 & $\mathrm{~A}$ \\
Ixodes sp. & 3 & 0.69 & 0 & $\mathrm{~A}$ \\
P. r. roberti & 2 & 0.69 & 0 & $\mathrm{~A}$ \\
M. apicalis & 1 & 0.69 & - & - \\
\hline
\end{tabular}

A: Amblyoma; A: Androlaelaps; G: Gigantolaelaps; H: Haemaphysalis; M: Metacutereba; P.r.: Polygenis roberti; $a$ : $\log _{10}$ of the frequency; $b$ : means followed by the same letter, did not differ significantly at the $5 \%$ overall level of probability, when Duncan's multiple comparisons test was used; N: number of observations; DF: degrees of freedom

TABLE II

Mean numbers of parasitic arthropods collected from three different rodent hosts at the Juréia-Itatins Ecological Station, State of São Paulo, Brazil, March 1989-February 1990

\begin{tabular}{|c|c|c|c|c|c|c|c|}
\hline Arthropods & Dry months (N) ${ }^{a}$ & Wet months (N) ${ }^{a}$ & DF & $t$ & $P$ & & \\
\hline A. cajennense (nymphs) & 0.79 & (4) & 0.81 & $(17)$ & 19 & 0.17 & 0.8689 \\
\hline A. cajennense (larvae) & 1.15 & (8) & 1.26 & (15) & 21 & 0.38 & 0.7086 \\
\hline Amblyopinus sp. & 0.94 & (21) & 0.72 & (13) & 32 & 1.36 & 0.1824 \\
\hline A. (Haemolaelaps) sp. & 1.65 & (32) & 1.68 & (49) & 79 & 0.14 & 0.8900 \\
\hline G. gilmorei & 1.63 & (41) & 1.71 & (69) & 67.8 & 0.48 & 0.6341 \\
\hline G. oudemansi & 2.41 & (78) & 2.42 & (134) & 210 & 0.05 & 0.9641 \\
\hline H. leporispalustris & 0.69 & (2) & 0.69 & (1) & - & - & - \\
\hline Ixodes sp. & 0.75 & (7) & 0.69 & (7) & 6 & 1.00 & 0.3559 \\
\hline M. apicalis & 0.69 & (6) & 0.91 & (12) & 11 & 2.64 & 0.0229 \\
\hline P. r. roberti & 1,03 & (29) & 1,20 & $(35)$ & 59.7 & 1.52 & 0.1338 \\
\hline
\end{tabular}

A: Amblyoma; A: Androlaelaps; G: Gigantolaelaps; H: Haemaphysalis; M: Metacutereba; P.r.: Polygenis roberti; a: Log 10 of the frequency; N: number of observations; DF: degrees of freedom; $t$ : t-test values; $P$ : probabilities 
neck (Bossi \& Bergallo 1992), and the beetles Amblyopinus sp., were attached to the base of the tail.

$O$. russatus was the most abundant host and also had the highest prevalence of ectoparasites. G. oudemansi, the most commonly collected ectoparasite, was recovered almost exclusively from $O$. russatus. According to Gettinger (1987), species of Gigantolelaps are restricted to the genus Oryzomys. Only one species of flea, $P . r$. roberti, parasitized this host, and showed a strong association with $O$. russatus, since $98.1 \%$ of the fleas were found on this host. According to Linardi (1984), Oryzomys is the main host genus for $P$. r. roberti. Larvae of $M$. apicalis were found on $O$. russatus. Although this parasite is large compared to the host, apparently it did not affect the survival of the parasitized rodents since previously infested hosts were recaptured with scars caused by the larvae leaving the host to pupate.

Linardi et al. (1991) found A. $i$. intermedia on the marsupial Lutreolina crassicaudata (Desmarest), and Guitton et al. (1986) found P. r. roberti on two species of Nectomys, two species of Oryzomys, two species of Oxymycterus, and on Rattus norvegicus (Berkenhout), Rhipidomys mastacalis (Lund) and Proechimys dimidiatus (Günther). Two acarine species, G. oudemansi and $H$. leporispalustris, were collected on P. iheringi, but they also occur on the marsupial M. nudicaudatus (Bossi 1996), which probably preys on $P$. iheringi.

The presence of only one Amblyopinus sp. was not surprising. Fonseca (1939b) collected A. gahani Fauvel on $N$. squamipes at Teresópolis and one of the authors (HGB) captured $N$. squamipes with Amblyopinus sp. in a region close to the study area. One unidentified species of Amblyopinus has been recovered from the marsupial $P$. frenata (Bossi 1996). Ashe and Timm (1987) suggest that the interaction between Amblyopinus and their hosts is probably mutualistic.

Few individuals of $N$. squamipes, a semi-aquatic rat, were captured, possibly because few traps were placed close to water. Ectoparasites were scarce on this rodent, contrasting with the findings of Linardi et al. (1987) who reported parasitism by other mites and fleas on this rodent.

The variation in rainfall between the driest and wettest months was high, but even in the dry months, the rainfall averaged approximately $100 \mathrm{~mm} / \mathrm{mo}$. The relationship between parasite intensity and period of the year was significant only for $M$. apicalis on the host $O$. russatus. The cuterebrid $M$. apicalis showed a higher incidence in the wet months as reported by Bossi and Bergallo (1992) and Vieira (1993).

According to JR Botelho (Universidade Federal de Minas Gerais, pers. commun.), Ixodes sp. found on the rodents, could be either I. amarili Fonseca or I. loricatus Neumann. The marsupials $D$. aurita, $M$. nudicaudatus and $P$. frenata were collected during this work and were parasitized by I. loricatus. This could also be the same tick species parasitizing the rodents.

The ectoparasites found on $O$. russatus showed differences in their intensities and can be separated into three groups, one formed by the mite G. oudemansi, and the other two by the remaining ectoparasites. $G$. oudemansi differed from the other parasites due to its high rates of prevalence on $O$. russatus.

\section{ACKNOWLEDGMENTS}

To the late Lindolpho R Guimarães for help with identification of the fleas, Ângelo P Prado for identification of the flies, Donald D Gettinger for identification of the laelapid mites, José Ramiro Botelho and Stephen Bennett for identification of the ticks and A Langguth, for identification of the hosts.

\section{REFERENCES}

Ashe JS, Timm R M 1987. Predation by and activity of "parasitic" beetles of the genus Amblyopinus (Coleoptera: Staphylinidae). J Zool 212: 429-437.

Barros DM, Baggio D 1992. Ectoparasites Ixodida Leach, 1817 on wild mammals in the state of Paraná, Brazil. Mem Inst Oswaldo Cruz 87: 291-296.

Barros DM, Linardi PM, Botelho JR 1993. Ectoparasites of some wild rodents from Paraná State, Brazil. J Med Entomol 30: 1068-1070.

Barros-Battesti DM, Arzua M, Linardi PM, Botelho JR, Sbalqueiro IJ 1998. Interrelationship between ectoparasites and wild rodents from Tijucas do Sul, State of Paraná, Brazil. Mem Inst Oswaldo Cruz, 93: 719-725.

Bergallo HG 1994. Ecology of a small mammal community in an Atlantic Forest area in southeastern Brazil. Studies on Neotrop Fauna and Environ 29: 197-217.

Bossi DEP 1996. Ectoparasitismo em Pequenos Mamíferos da Estação Ecológica de Juréia-Itatins, Iguape (SP), MSc Thesis, Universidade Estadual de Campinas, Campinas, Brasil, 89 pp.

Bossi DEP, Bergallo HG 1992. Parasitism by cuterebrid botflies (Metacuterebra apicalis) in Oryzomys nitidus (Rodentia: Cricetidae) and Metachirus nudicaudatus (Marsupialia: Didelphidae) in a southeastern Brazilian rain forest. $J$ Parasitol 78: 142-145.

Botelho JR, Linardi PM, Williams P, Nagem RL 1981. Alguns hospedeiros reais de ectoparasitos do município de Caratinga, Minas Gerais, Brasil. Mem Inst Oswaldo Cruz 76: 57-59.

Bush AO, Lafferty KD, Lotz JM, Shostak AW 1997. Parasitology meets ecology on its own terms: Margolis et al. revisited. J Parasitol 83: 575-585.

Carvalho RW, Serra-Freire NM, Linardi PM, Almeida AB, Costa JC 2001. Small rodents fleas from the bubonic plague focus located in the Serra do Órgãos mountain range, State of Rio de Janeiro, Brazil. Mem Inst Oswaldo Cruz 96: 603-609.

Fonseca FOR 1939a. Espécies de Amblyopinus parasitas de murídeos e didelfídeos em São Paulo (Coleoptera, Staphylinidae). Mem Inst Butantan 12: 191-194.

Fonseca FOR 1939b. Observação de uma fase do ciclo evolutivo de Cuterebra apicalis Guérin (Diptera: Oestridae). Mem Inst Butantan 12: 195-196.

Gettinger D 1987. Host associations of (Acari: Laelapidae) in the Cerrado Province of central Brazil. J Med Entomol 24: 559-565.

Gettinger D 1992. Host specificity of Laelaps (Acari: Laelapidae) in Central Brazil. J Med Entomol 29: 71-77.

Guimarães LR 1945. Sobre alguns ectoparasitos de aves e mamíferos do litoral paranaense. Arq Museu Paranaense 4: 179-190.

Guitton N, Araújo-Filho NA, Sherlock IA 1986. Ectoparasitos de roedores e marsupiais no ambiente silvestre de Ilha Grande, Estado do Rio de Janeiro, Brasil. Mem Inst Oswaldo Cruz 81: 233-234.

Kettle DS 1985. Medical and Veterinary Entomology, WileyInterscience, New York, 658 pp. 
Kim KC 1985. Coevolution of Parasitic Arthropods and Mammals, Wiley-Interscience, New York, 800 pp.

Linardi PM 1977. Relações pulgas/roedores observadas nos municípios de Salesópolis e Itapetininga, SP. Bol Museu Hist Nat UFMG Zool 23:1-25.

Linardi PM 1985. Dados complementares sobre hospedeiros de sifonápteros ropalopsilinos. Revta Bras Biol 45: 73-78.

Linardi PM, Guimarães LR 2000. Sifonápteros do Brasil, Museu de Zoologia, USP/Fapesp, São Paulo, 291 pp.

Linardi PM, Botelho JR, Neves DP, Cunha HS 1984. Sobe alguns ectoparasitos de roedores silvestres de Belo Horizonte, MG. Revta Bras Biol 44: 215-219.

Linardi PM, Botelho JR, Ximenes A, Padovani CR 1991. Notes on ectoparasites of some small mammals from Santa Catarina, Brazil. J Med Entomol 28: 183-185.

Linardi PM, Teixeira VP, Botelho JR, Ribeiro LS 1987. Ectoparasitos de roedores em ambientes silvestres do município de Juiz de Fora, Minas Gerais. Mem Inst Oswaldo Cruz 82: 137-139.

Monteiro-Filho ELA 1987. Biologia Reprodutiva e Espaço Domiciliar de Didelphis albiventris em uma Área Perturbada na Região de Campinas, Estado de São Paulo, MSc Thesis, Universidade Estadual de Campinas, Campinas, 89 pp.

Nascimento CM, Pereira MAMG 1988. Atlas Climatológico do Estado de São Paulo (1977-1986), Fundação Cargill, Campinas, $93 \mathrm{pp}$.

Paixão ILSC 1984. Estação Ecológica da Juréia. Ministério do Interior, Secretaria Especial do Meio Ambiente, Brasília, $42 \mathrm{pp}$.

SAS Institute, Inc. 1987. S.A.S. User's Guide: Statistics, Version 6th ed., Cary, N.C.

Vieira EM 1993. Occurrence and prevalence of bot flies, Metacuterebra apicalis (Diptera: Cuterebridae), in rodents of cerrado from central Brazil. J Parasitol 79: 792-795. 
